\title{
Effect of Organizational Commitment and Work Motivation on Job Satisfaction and Individual Performance
}

\author{
Sarwani $^{1}$, Andry Herawati ${ }^{2}$, Liling Listyawati ${ }^{3}$, Damajanti Sri Lestari ${ }^{4}$ \\ \{sarwani@unitomo.ac.id ${ }^{1}$, andry.herawati@unitomo.ac.id ${ }^{2}$, liling.listyawati@unitomo.ac.id ${ }^{3}$ \} \\ ${ }^{1,2,3,4}$ Fakultas Ilmu Administrasi Universitas Dr. Soetomo Surabaya, Indonesia
}

\begin{abstract}
This study aims to empirically analyze and prove the effect of work motivation and organizational commitment on job satisfaction and individual performance. It is very important that individual performance becomes an inseparable part of performance management and that it is the basis and driver of organizational decision-making, work initiatives, and human resources to make effective decisions. This study compiled a total of 120 questionnaires representing the management, supervisors, supervisors of field instructors and the staff responsible for providing services to women members of the "Setia Bhakti Wanita" cooperative in East Java. The results indicate that work motivation and organizational commitment have a significant positive effect on job satisfaction. Work motivation has no significant effect on individual performance, while organizational commitment and job satisfaction have a significant positive effect on individual performance
\end{abstract}

Keywords: Organizational commitment, motivation at work, job satisfaction and individual performance.

\section{Introduction}

One of the most important and crucial organizational resources to use is human resources, which are explicitly designated as employees. The effective achievement of organizational goals can be measured by organizational performance units. Organizational performance is the accumulation of the performance of each individual or employee. Employee performance is often interpreted as results or performance at work in an organization or company. Management of employee performance as an individual according to Wibowo [1] will bring benefits in the form of: clarifying roles and objectives, encouraging and supporting to look good, helping to develop capacity and performance, having the opportunity to use quality time, as a basis for objectivity and honesty to measure performance, and formulate goals and plans to improve the work to be managed and executed.

The results of the Jayaweera study [2] show that there is a significant relationship between the physical environment, psychology, and motivation at work and employee performance. The observed influence shows that the physical environment has a significant positive effect on employee performance, while the psychological environment and motivation at work have no significant effect on employee performance. The work environment, which is supposed to explicitly indicate working conditions, which are also external motivators, is closely linked to the professional performance of employees, such as the results of the studies presented by Mohapatra and Srivastava [3]; Naharuddin and Sadegi [4]; Chandrasekar [5]; and Vischer [6]. The results of the study by Aisha, Hardjomidjojo, and Yassierli [7] showed that 
incentives, working conditions, and motivation at work had a significant effect on the performance of employees of the University of Indonesia. Also, he acts as a moderator and mediator of the influence of workplace characteristics on employee performance.

While the results of the Tiwari study [8] indicate that there is an impact on job satisfaction on employee performance. The most important factors in contributing to job satisfaction are: a pleasant workplace, excellent employee relations, every hour of work is respected, demonstrates a sense of justice, participates in the taking decision making, offers development opportunities in the future, and overall satisfaction with all the work of employees.

The results of the [9] and [10] study indicate that organizational commitment is significant and significant anticipation of various organizational arrangements and the existence of differences in the organizational culture environment. However, the results of the study show that job satisfaction has a significant effect on organizational commitment to employees in the private and public sectors, which effectively predicts the organization's commitment. The results of the Imran, Arif, Cheema and Azeem study [11] showed that attitudes towards work were positively and significantly related to job satisfaction and positively and significantly related to employee performance; organizational commitment does not significantly affect job satisfaction, but is positively and significantly related to employee performance; and job satisfaction is positively and significantly related to employee performance.

The existence of the "Setia Bhakti Wanita" women's cooperative in East Java has a copy of the notary act $\mathrm{n}^{\circ} 18$ dated April 17, 2012 and authorized by the integrated service license management unit of the province of East Java bearing the $n^{\circ} \mathrm{P} 2$ / 3 / 09.02 / VI / 2012 of June 29, 2012 with the vision: as a character, independent organization, fair and prosperous based on the responsibility. While the mission accomplished is to achieve: quality human resources; improve the quality of the service; creative and innovative sustainable cooperative independence; the well-being of members, managers, and the community; and equitable and inclusive leadership models. The business units belonging to the cooperative consist of commercial entities: common savings and credit, savings and SME loans or not, models of joint liability, stores, and training centers. This study aims to empirically analyze and prove the effect of work motivation and organizational commitment on job satisfaction and individual performance.

\section{Theoretical journals}

\subsection{Individual performance and job satisfaction}

Understanding Individual Performance, In this case, the employee is a formal evaluation by the boss or manager to subordinates of their performance over a certain agreed period of time. Wibowo [1] stated that the employee's performance was evaluated by line managers or managers called evaluators and subordinates or employees considered to be the evaluation. If an employee performance review is conducted more often, the boss or manager or his or her subordinate or employee will receive benefits for both parties. Bosses or managers have better opportunities to maintain productivity, while subordinates or employees gain up-to-date knowledge of their performance and at the same time have the opportunity to improve. The measure of performance varies so much that there are flexible and selectable usage options that are appropriate or relevant to the type of business of each organization. Therefore, for coops, the weight of monetary size, time size, influence and response indicators is critical to measuring employee performance. 
According to Greenberg and Baron [12], job satisfaction is a positive or negative attitude on the part of employees about their tasks and jobs. There is a two-factor job satisfaction theory that suggests that satisfaction and dissatisfaction are part of a different group of variables, namely motivational factors and hygiene factors. In general, people expect a certain factor to be satisfactory when it is available and to cause discontent when not present. The theory of dissatisfaction will be related to the conditions surrounding the work rather than to the work itself. Therefore, this factor prevents negative reactions, often called hygiene or maintenance factors. Conversely, satisfaction comes from factors related to the work itself or the direct results of the worker, such as the nature of the work, the results obtained, opportunities for promotion and personal development and recognition; these factors are then associated with a high level of job satisfaction, often called motivational factors.

\subsection{Organizational commitment and motivation at work}

This organizational commitment is a person's commitment to the organization in the workplace. Luthans [13] states that organizational commitment is a strong desire to remain a member of a particular organization, the desire of someone to strive according to the wishes of the organization and to respect certain beliefs and to accept values and objectives of the organization. Robbins [14] states that the organizational commitment includes the attitude of a person or employee as to the extent to which a person or employee is related to a particular organization and objectives and wishes to remain as a member of the organization. Therefore, with a strong involvement in specific tasks and jobs, the organizational commitment is also high, which means that the person has clearly committed themselves as a member of the organization that has employed it.

Motivation according to Kreitner and Kinicki [15] states that motivation is a psychological process that evokes and orients behavior toward goal-setting or goal-oriented behavior. Whereas Robbins [14] defines motivation as a process that has brought about both the direction and the ongoing efforts of an individual to achieve goals. The intensity is indicated by the strength or force that someone has tried. This is the time. By the mobile, on the impact of the quality of a base on continues, and the sound of mint.

\section{Methods}

The population consists of all the directors, supervisors, extension officers (PPL) and SETIA BAKTI (East Java) employees who provide services to members of the cooperative. The number of samples is 120 respondents with the reasoned sampling technique. The data analysis used descriptive analysis to describe the results of the data processing according to the needs of the research. The validity and reliability of the data were tested and then processed using computer software packages with AMOS 20 to obtain the results of the path analysis processing. Data analysis uses path analysis to test the magnitude of the path coefficient for each path diagram that shows a causal link between work motivation, organizational commitment, and job satisfaction with individual performance. A causal relationship that shows the influence between the variables that will appear appears in the study results

\subsection{Description of the variables}

Work motivation variables are measured using 5 item statements. The description of the evaluation of work motivation variables is indicated by an average score of 4.03 between 3.4 
and 4.2 (agree / high). Organizational commitment variables are measured using 9 item statements. The description of the evaluation of organizational commitment variables is indicated by an average score of 3.84, ranging from 3.4 to 4.2 (agree / high). Job satisfaction variables are measured using 5 item statements. The description of the assessment of job satisfaction variables is indicated by an average score of 3.73, ranging from 3.4 to 4.2 (agree / high). Individual performance variables are measured using 5 elements or items of utterance. The description of the evaluation of the individual performance variables is indicated by an average score of 3.52 , ranging from 3.4 to 4.2 (agree / high).

\section{Result and Discussion}

\subsection{Result}

\subsubsection{Validity and reliability test results.}

The Pearson Moment correlation test for each job posting on work motivation, organizational commitment, job satisfaction, and individual performance variables achieved a significance value of less than $5 \%$. This indicates that all the instruction elements used to measure all variables are valid and can be used for further analysis. The results of the questionnaire reliability test yielded the Cronbach alpha value for all value variables greater than 0.60 so that the preparation of the questionnaire's reporting elements can be considered as a variable motivation, a motivation to work, to be considered as a coherent measuring instrument.

\subsubsection{Path Analysis Results}

\subsubsection{Hypothesis test}

The linearity test can be performed with a curve adjustment. If the results of the F test via Anova produce a significance value of less than $5 \%$, then it is indicated that the relationship path between the variables is linear. The results of the linearity tests are presented in the following table

Table 1. Linearity test results in inter-variable relationships

\begin{tabular}{lllccc}
\hline & Path & F test & Sig. & Explanation \\
\hline Work Motivation & $\rightarrow$ & Job Satisfaction & 21,057 & 0,000 & Linear \\
Organizational & $\rightarrow$ & Job Satisfaction & 8,008 & 0,005 & Linear \\
Commitment & & & & & \\
Work Motivation & $\rightarrow$ & Individual Performance & 4,811 & 0,030 & Linear \\
Organizational & $\rightarrow$ & Individual Performance & 41,077 & 0,000 & Linear \\
Commitment & & & & & \\
Job Satisfaction & $\rightarrow$ & Individual Performance & 33,777 & 0,000 & Linear \\
\hline
\end{tabular}

Table 1 shows the results of the F test by ANOVA on the five relationship paths between all the variables, giving a value of significantly less than 5\%. It was therefore concluded that the relationship path between variables in the search pattern was entirely linear.

a. The recursive model, the model developed in this study, was recursive (unidirectional) and nonreciprocal (round trip) so that the assumptions are fulfilled.

b. The dependent variable is measured at least in the interval scale

In this study, the scale of the data used is that of Likert or that of the ordinal scale. But Edward and Kennedy in Ghozali [16] argue that ordinal scales can be considered as 
intervals since ordinal scales have a similarity level of $92 \%$ compared to if they are measured by the interval scale.

c. Each variable is measured without error (valid and reliable instruments). In the previous section, the questionnaire was valid and reliable.

d. The model is correctly specified according to theory and concept.

The model developed in this study was specified on the basis of the theory and the concept set out in Chapter 2 so that the relevant assumptions have been fulfilled.

\subsubsection{Results of path estimates or path coefficient}

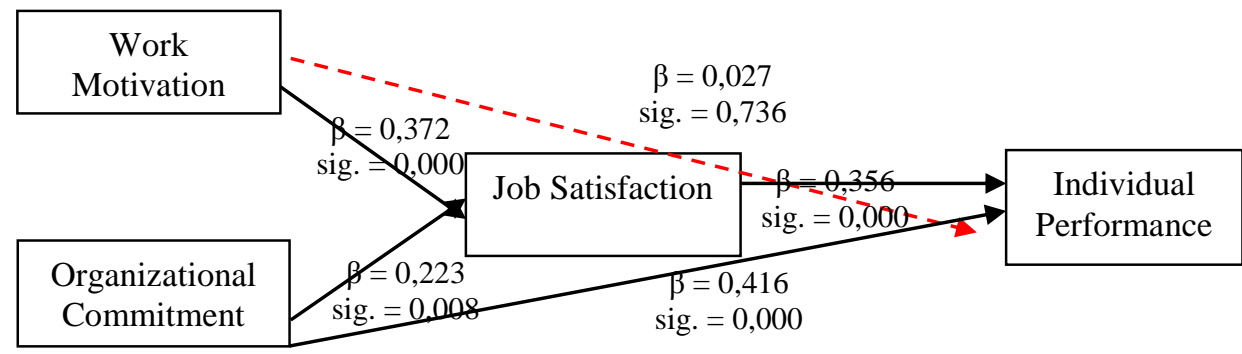

Fig. 1. Results of path estimates or path coefficient

\subsubsection{Direct effect and indirect effect}

Below are the results of the direct and indirect effects with the values of the propagation coefficient (beta) for each relationship between the search variables presented in Table 2, as follow

Table 2. Coefficient (beta) of each path

\begin{tabular}{|c|c|c|c|c|}
\hline \multicolumn{2}{|c|}{ Correlation } & $\begin{array}{l}\text { Direct } \\
\text { Effect }\end{array}$ & $\begin{array}{c}\text { Indirect } \\
\text { Effect }\end{array}$ & $\begin{array}{c}\text { Total } \\
\text { Effect }\end{array}$ \\
\hline Work Motivation & Job Satisfaction & 0,372 & - & 0,372 \\
\hline Organizational Commitment & Job Satisfaction & 0,223 & - & 0,223 \\
\hline Work Motivation & Individual Performance & 0,027 & 0,132 & 0,159 \\
\hline Organizational Commitment & Individual Performance & 0,416 & 0,079 & 0,496 \\
\hline Job Satisfaction & Individual Performance & 0,356 & - & 0,356 \\
\hline
\end{tabular}

Table 2 shows the following results:

1) The most influential variable on job satisfaction is work motivation, because it has the largest total effect, at 0.372 , then the organizational commitment is 0.223

2) The most influential variable on individual performance is organizational commitment because

The most important total effect is 0.496 , then job satisfaction is 0.356 and the last job motivation is 0.159 . 


\subsection{Discussion}

Effect of work motivation on job satisfaction. In this study, motivation at work has a positive value or in the sense of job satisfaction. This indicates that each manager, supervisor, supervisor of field counselors and employees who provide services to co-op members with a high motivation to work also get higher job satisfaction. Thus, the first hypothesis that states the effect of work motivation on job satisfaction can be accepted and proven.

Effect of organizational commitment on job satisfaction. The test results from the second hypothesis indicate that organizational commitment has a positive value or in the direction of job satisfaction. This indicates that each manager, supervisor, supervisor of field instructors and employees who are committed to the organization's ability to provide cooperative services to members benefits from the professional satisfaction that they feel is elevated. Thus, the second hypothesis, which states an influential organizational commitment to job satisfaction, can be accepted and proven.

Effect of work motivation on individual performance. The results of the third hypothesis test indicate that work motivation does not have a significant impact on its performance. This indicates that each manager, supervisor, supervisor of field counselors, and employees who have a high or low motivation to provide services to co-op members does not mean the impact on the performance they produce. We can say of this event, even if the motivation to work contributes to providing services to the members. cooperatives but had no real impact on the performance of management, supervisors, supervisors of extension agents and employees. Thus, the third hypothesis that work motivation affects individual performance is rejected and unproven.

Effect of the organization's commitment to individual performance. The test results of the fourth hypothesis indicate that organizational commitment has a positive value or in the direction of individual performance. This indicates that each manager, supervisor, supervisor of field counselors and employees who are committed to the organization in providing services to co-op members improve their performance. Thus, the fourth hypothesis that organizational commitment affects individual performance is acceptable and proven.

Effect of job satisfaction on individual performance. The results of the fifth hypothesis test indicate that job satisfaction is positive or in line with individual performance. This indicates that each manager, supervisor, supervisor of field instructors and employees who feel satisfied with providing services to co-op members also improves their performance. Thus, the fifth hypothesis that job satisfaction affects individual performance can be accepted and proven.

\subsubsection{Examination of the validity of the model}

The coefficient of determination (R2), the influence of work motivation and organizational commitment on job satisfaction are equal to 0.201 , which indicates the magnitude of the influence of job motivation and job satisfaction. organizational commitment on job satisfaction for administrators, supervisors, advisors, and employees of the "Setia Bhakti Wanita" cooperative in East Java is $20.10 \%$, while the remaining $79.90 \%$ is influenced by other variables. The coefficient of determination (R2), the effect of work motivation, organizational commitment and job satisfaction on individual performance is 0.385 , which means that the influence of job motivation, job satisfaction organizational commitment and job satisfaction on the performance of individual directors, supervisors, supervisors, and employees of the "Faithful Bhakti Wanita" cooperatives in East Java account for 38.50\%, the remaining $61.50 \%$ being influenced by other variables. 


\subsubsection{The results of the calculation of the total coefficient of determination $(\mathrm{Rm})$ can be performed}

$$
\begin{aligned}
& \text { Pe1 }=\sqrt{ } 1-\mathrm{R} 12=\sqrt{ } 1-0,201=0,894 \\
& \text { Pe2 }=\sqrt{ } 1-\mathrm{R} 22=\sqrt{ } 1-0,385=0,784 \\
& \mathrm{Rm}=1-(\operatorname{Pe} 12 \times \text { Pe22 })=1-0,491=0,509
\end{aligned}
$$

The results of the calculations can indicate that the model developed in this study can explain 50,90\% of the information contained in the data or the contribution of the influence of the independent variables on the dependent variable to $50,90 \%$, while the 49 , The remaining $10 \%$ are explained. influenced by variables, other models or errors in intimidatory or errors in this study, so that the entire model developed can be considered very good.

\subsubsection{Hypothesis tests}

The results of the hypothesis tests influence the variables using the results of the path analysis:

Table 3. Hypothesis Testing Results

\begin{tabular}{lllccc}
\hline & \multirow{2}{*}{ Jalur (Path) } & & Korf. & $\mathrm{t}$ & \multirow{2}{*}{ Sig. } \\
\hline Work Motivation & $\longrightarrow$ & Job Satisfaction & 0,372 & 4,484 & $0,000^{(\mathrm{s})}$ \\
Organizational Commitment & $\longrightarrow$ & Job Satisfaction & 0,223 & 2,690 & $0,008^{(\mathrm{s})}$ \\
Work Motivation & $\longrightarrow$ & Individual Performance & 0,027 & 0,337 & $0,736^{(\mathrm{ss})}$ \\
Organizational Commitment & $\longrightarrow$ & Individual Performance & 0,416 & 5,530 & $0,000^{(\mathrm{s})}$ \\
Work Motivation & $\longrightarrow$ & Individual Performance & 0,356 & 4,376 & $0,000^{(\mathrm{s})}$ \\
\hline Description: significant (s); (ts) not significant & & &
\end{tabular}

The results of the hypothesis test in Table 3 explain that the results of the estimation of the coefficient of flow of motivation at work lead to job satisfaction, to the organization's commitment to job satisfaction, organization's commitment to individual performance and job satisfaction with individual performance 5\% (Abbreviation $\leq 5 \%$ ), but work motivation for individual performance produces a value of significance greater than $5 \%$ (Sig. $\geq 5 \%$ )

The results of the tests carried out on the assumptions made also imply that job satisfaction means fully (full mediation) that motivation at work influences individual performance, which means that high motivation at work cannot affect individual performance. only if it is balanced with high job satisfaction. In addition to being something different from work motivation, job satisfaction partially or partially (partially mediated) influences the influence of organizational commitment on individual performance, which means that a strong commitment organization can directly influence individual performance or indirectly through the mediation of job satisfaction. 


\section{Conclusion}

The results of the study on the verification of direct effects and indirect effects in the relationship between research variables indicate that the most important motivation for job satisfaction is the motivation at work, followed by a variable organizational commitment. The results of the direct effect and the indirect effects on the individual performance show that the most influential is the variable organizational commitment rather than job satisfaction and organizational commitment. The test results on the five assumptions imply that job satisfaction fully influences (fully mediated) the effect of work motivation on individual performance. This means that a strong motivation to work can only affect the performance of individuals balanced by high job satisfaction.

\section{References}

[1] Wibowo, Manajemen Kinerja, Edisi Keti. Jakarta: PT Rajagrafindo Persada, 2007.

[2] T. Jayaweera, "Impact of Work Environmental Factors on Job Performance, Mediating Role of Work Motivation: A Study of Hotel Sector in England," Int. J. Bus. Manag., vol. 10, no. No. 3, 2015.

[3] B. K. Mohapatra and A. K. Srivastava, A study of the Relationship of Perceived Work Environment with Job Attitude, Performance, and Health. Unpublished Ph.D. Department of Psychology, Banaras Hindu University, 2003.

[4] N. M. Naharuddin and M. Sadeghi, "Factors of Workplace Environment that Affect Employees Performance: A Case Study of Miyazu Malaysia," Int. J. Indep. Res. Stud., vol. 2, no. 2, pp. 66-78, 2013.

[5] K. Chandrasekar, "Workplace Environment and Its Impact on Organizational Performance in Public Sector Organizations," Int. J. Enterp. Comput. Bus. Syst., vol. 1, no. 1, pp. 1-20, 2011.

[6] J. C. Vischer, "Towards an Environmental Psychology of Workplace: How People are Affected by Environments for Work," Archit. Sci. Rev., vol. 51, no. 2, pp. 97-108, 2008.

[7] A. N. Aisha, P. Hardjomidjojo, and Yassierli, "Effects of Working Ability, Working Condition, Motivation and Incentive on Employees Multi-Dimensional Performance," Int. J. Innov. Manag. Technol., vol. 4, no. 6, 2013.

[8] U. Tiwari, "An Analysis of job satisfaction and its impact on employees performance at life insurance corporation (LIC) of India," Abhinav Int. Mon. Ref. J. Res. Manag. Technol., vol. 3, no. 11, 2014.

[9] M. J. Clugston, "Does the culture socialization predict multiple bases and for of commitment," J. Manage., vol. 3, pp. 5-30, 2002.

[10] P. B. Smith, "Cross-Cultural Industrial-Organizational Psychology (1, ed.)," Int. Rev. Ind. Organ. Psychol., vol. 16, pp. 174-193, 2001.

[11] H. Imran, I. Arif, S. Cheema, and M. Azeem, "Relationship between job satisfaction, job performance, attitude towards work, and organizational commitment," Entrep. Innov. Manag. J., vol. 2, no. 2 (May 2014), pp. 135-144, 2014.

[12] J. Greenberg and R. A. Baron, Behavior in Organizations. New Jersey: Prentice-Hall, 2003.

[13] F. Luthans, Perilaku Organisasi, Edisi Sepu. Yogyakarta: Andi Offset, 2005.

[14] S. P. Robbins, Organizational Behavior. New Jersey: Prentice-Hall, 2003.

[15] R. Kreitner and A. Kinicki, Organizational Behavior. New York: McGraw-Hill Companies, Inc., 2001.

[16] I. Ghozali, Structural Equation Modeling, Teori, Konsep, dan Aplikasi Dengan Program 
Lisrel 8.80. Semarang: Badan Penerbit Universitas Diponegoro, 2008. 